\title{
Image Analysis of the Characters in The Scarlet Letter
}

\author{
Yanmei Song \\ School of Foreign Language \\ Nanyang Institute of Technology \\ Nanyang, China
}

\begin{abstract}
The Scarlet Letter is recognized as the authoritative work of Nathaniel Hawthorne who is the most significant romantic writer in American literature in the 19th century. This thesis attempts to take the novel The Scarlet letter as the text, analyses the different images of Hester, Dimmesdale, Chillingworth and Pearl by the contrast methods and summarizes the revelations for the readers from their tragic life. These image analysis reveals the truth that different choices decide different fates.
\end{abstract}

Keywords-Hester; Dimmesdale; Chillingworth; Pearl; revelation

\section{INTRODUCTION}

The Scarlet letter is written by Nathaniel Hawthorne, who is one of the most famous romanticism and psychological novelists in the 19th century in the United States. Its publication is a breakthrough in the history of American novel creation. It is hailed as one of the best novels in the history of American literature in the 19th century.

The characters' tragedies exist throughout in The Scarlet Letter. Hawthorne uses the tragic tone of the full text from the start. The first scene is a group of pilgrims with dull clothes gather in the wooden prison, the heroine is coming out of the prison gate, with her newly born daughter in her arms, and wearing a gown with the scarlet letter "A" on it... Hawthorne arranges different tragedies for the four main characters. Through the analysis of their tragic life, we can understand their respective different life endings deeply.

\section{THE BRAVE TRANSIGENT - HESTER}

The heroine Hester is the main character in The Scarlet Letter. She has an inseparable relationship with her husband Chillingworth and her lover Dimmesdale. In the emotional entanglement with the two men, her impression to readers is brave and strong. When Hester stands on the scaffold and refuses to confess the adulterer's name firmly once again, her personality has got full display. Her behavior is the protection of lover, also the struggle for the church rule, disdain for pedantic secular ideas and the negation of the crimes. Therefore, Hester is a female image in the readers' field of vision initially who is against social secular and religious rule. The brave and resistance in the character of
Hester is the author's ideal, but it must be consistent with the turbulent period, the complexity of the social thought and the specific living environment and identity of the characters. So when the author praises brave and resistance in her personality, compromise which behind it is more important.

With the development of the plot, Hester's strong personality has become blurred. In the beginning, she is the most beautiful woman in the town, wearing the delicate clothes with the scarlet letter " $A$ " on it. We can see her independent aesthetic consciousness and contempt of Puritan laws from her appearance. While several years later, she always wears the grey linen clothes, and none of her elaborate handicrafts is on herself, she becomes a person who follows Puritan traditions, even cannot see the gender. In her behavior, on the one hand, she shows strong resistance and refuses to compromise for the church when exposed in the scaffold and competing for her daughter's custody. On the other hand, when Chillingworth appears, she is so fear that succumbs to his threat, and keeps silence on his true identity for seven years. All these can explain that Hester has accepted completely and submitted to her "guilt" which settled by the traditional values for her past.

From the development of Hester's personality, we can see that courage and revote are always accompanied by compromise. She lives in the North American colonial society in the $17^{\text {th }}$ century that religious and theocratic thoughts occupy a dominant position. The strong force of religious exists everywhere, and the suffocating religious spirit poisons people's minds, just like the opium. "Hester has the desire to aspire happiness, but cannot get rid of the bondage and imprison of religious thoughts completely, it makes her compromise on thought and behavior." She knows that her love with Dimmesdale has its own sacredness, but also thinks that her behavior violates religious precepts, and she is evil in the presence of God. Although she does not believe in religion, even hold a denial attitude to the religious regulations, but hope that her daughter can become a devout Christian. It seems that Pearl can avoid her fate as long as she acts in accordance with the Puritan regulations strictly. She believes that all the relationships between men and women will be based on both happiness, but advises her sisters who are suffering to be patient and wait, as if the period of light will come itself. 
Therefore, in the development of the plot of The Scarlet Letter, although Hester has strong rebellious spirit, even face to face with the church rule, disdain for worldly ideas and the pursuit of new life, but she still cannot get rid of the male domination which is the symbol of church, and to the spirit of all the people at that time is the religious rule. At that time, it is the religious rule what control people's spirit. In such an environment, Hester completes the return from a pioneer female fighter who is highly insulting and full of rebellious spirit to a conservative woman who is obdient to the religious edict. She is a woman who dares to love, but her passion for love is beyond the moral constraints, it leads to her adultery which abused by people. She is a victim that makes people feel sympathetic; she only can be a tragedy in the society which people's minds are twisted.

\section{The COWARDLY HyPOCRITE - DimMESDALE}

The handsome minister, Dimmesdale, with his elegant physical and shaking lips, shows his sensitive and cowardice everywhere.

$\mathrm{He}$ is the most painful and depressed one in the main characters. Hester can get the salvation of soul in the process of helping others, Chillingworth does not feel his guilty with his heart focus on the revenge, only Dimmesdale is tortured by hidden evil every day.

"Graduated from the famous university, he comes to this remote town with advanced and rich knowledge, but he nearly never enjoys happiness or gets any redemption here." As a minister, he commits adultery but dare not to bear the responsibility, it exposes his cowardly and selfish personality. His crime is same with Hester's, if he has the courage to admit his crime, his crime may not be serious as Hester's. However, they commit the same fault, but their fates are so different. Hester releases her sin to the public, while Dimmesdale only hides his sin in the heart and accepts his own endless inner punishment. The respected minister, Dimmesdale, teaches people the sermon of confession and redemption every day, but for himself, he can not to do it. "Dimmesdale becomes sensitive and cowardice because of the need to conceal the secret carefully, when there is any emergency, he will look pale." Chillingworth takes advantage of his characteristic, brings pressure to him, and deepens his fear from the words and actions constantly. Fear makes him awake all night and stocked by the nightmare, makes him feel intimidated. Under this kind of mental state, his health deteriorates sharply; everyone sees that he is possessed by the evil. As what he says, his suffering is not less than Hester's in the seven years. Hester gets inner peace; while, what Dimmesdale gets is nothing expect despair.

"In addition to fear, Dimmesdale is also afflicted with self-accusation. For Hester, love is the strong driving force in her spirit world, makes her stronger. But for Dimmesdale, love becomes his nightmare, makes him more and more timid." Although he and Hester are truly in love, but because of his beliefs, he dares not to admit their love, he is always in regret. He feels that he is a man whose soul has been destroyed, what all he does is in no faith. Therefore, the more people respect him, the more painful he feels. "One side is his religious doctrine (asceticism) and the other side is his love, these make the young minister produces the tangled emotion in his inner which is hard to balance." Lack of spiritual nutrition, Dimmesdale is weakening gradually under the dual ordeal of conscience and the enemy, death hangs over him. In the final moments of life, he finally stands on the execution stage bravely, and reveals his crime to all people. This action not only makes him get rid of the enemy's torture; also lead him to release the burden of the heart at the same time. Finally, he can pass away quietly, though the peace comes a little later.

\section{The Murderous AVenger - Chillingworth}

"For many readers, Chillingworth seems to be an evil, an ugly man, while in fact he is also a tragic victim." When Chillingworth first appears, he is just released by the Indians. With the clothes mixed with "civilization and savage", he looks very terrible and ugly. Even though dressed, he is not attractive. He is not old, but has a wrinkled face. However, he is slightly intelligent indeed, his singular eyes what insight into everything can seem hazy and dim. Unexpectedly, in order to revenge, a diligent scholar who almost secludes from the world to seek knowledge becomes a devil figure.

The first thing Chillingworth sees when he arrives Boston is that his wife Hester has an affair and accepts the punishment of wearing the robe with a letter "A" (means Adultery) on it. In face of such situation, as a man, a husband, the humiliation and torture that he suffers is not less than Hester. The revenge to the minister Dimmesdale later, is it not a kind of torture to himself? As he is a simple, honest and educated scholar. Chillingworth, such a glamorous image becomes a poor, evil and ugly guy gradually; this is extremely tragic in itself. "What's more, he is totally in a passive position in the novel. He is the kidnapped victim, the victim of betrayal, the victim teased by fate; after all, he is the victim of the tragedy. The revenge swallows his minds and becomes his sole purpose to be alive."

"Chillingworth is the avenger in The Scarlet Letter, the only one who does not get inner peace after his death in the main characters." He is a victim, his wife Hester betrays him, and gives birth to her lover's child, he deserves the sympathy of people, and the author Hawthorne also shows deep sympathy for him. While the desire of hatred and revenge disorganizes his minds, he loses his minds and becomes a devil because of the cruel revenge to Dimmesdale. He always takes revenge on Dimmesdale, but in fact, his revenge does not succeed in the end. As Dimmesdale announces that he is the hidden committed adultery and then dies. With the death of Dimmesdale, Chillingworth loses the object of his revenge. This is more tragic than tragedy.

\section{THE INNOCENT VICTIM - PEARL}

Another tragic figure in the novel is Pearl, the innocent victim. "We can say that Pearl is the most wonderful and attractive character in the novel. When first appears, she is just a three months' baby. However, she is carved by the years, just likes her mother, has colorful beauty, bright 
complexion and twinkling eyes. "Unexpectedly, the little baby can show the beautiful bodily form and full of boundless vitality. Intelligent, curious, sometimes very stubborn, she is a baffling elf. The unruly temperament makes her to be an "elf", "ghost" in the book, unlike general children. Hester often cannot help asking, "O Father in Heaven - if Thou are still my Father-what is this being which I have brought into the world!"

Obviously, Pearl is the result of cheating between Hester and Dimmesdale. Her presence implies that the relationship between them is illegal. In the society which regards love as devil, in addition to the scarlet letter " $A$ " before Hester's chest, Pearl is another symbol of her disgrace. While Pearl is not a general object, she has emotions, flesh and blood. Pearl, shaped by Hawthorne, becomes the most moving and powerful symbol. From the first time she sees the letter before her mother's chest, she increases Hester's punishment unconsciously.

"In the novel, Hawthorne uses Pearl as the symbol of the tragic consequence of romantic love and crystallization of sin. She is a victim of the tragedy, as she is an illegitimate daughter whom no father admits and the evidence of her parents' crime. "She loses the rights that she should enjoy like other Christian children. She has no friend, no father's love, the only one time she enjoys her father's love is before her father's death. Her mother gives birth to her, but cannot provide the living environment like other children's, even cheat her about the meaning of the scarler letter A.

\section{THE REVELATION FOR READERS}

Although Hester commits adultery, she admits her crime and the more valuable is that she can show her crime to the world openly without any reservation. She never hides anything deliberately; she is saved from her real brave. Hester learns lessons from her unfortunate experience and becomes a good and helpful woman gradually. Finally, she gets others' respect for her. Hester proves her persistence for love with persevering life attitude. She does not indulge her lust and harm others, also not bound her pursuit with the sacred dogma, she is the master of fate. "Through the meticulous depicting of Hester, Hawthorne tells readers that everyone should have courage to admit his faults, atone for his crime through his own benevolence. Only in this way, one can get salvation and avoid more serious pain."

To the shame, Dimmesdale takes the opposite attitudeconcealing the truth. As a minister, he is aware of the consequences of adultery. He is afraid of losing the respected profession, losing his own reputation, more afraid of people's cynicism and isolated. Whatever he gives himself the stated reason, we can see that his timidity on the surface is caused by his inner cowardice. His inner conflict is the struggle with his weak character, but his only way out is to admit the fact openly. It is his weakness that leads to his tragic life. In the end, he announces that he is Pearl's father on Election Day publicly; regardless of the great honor that given by the general public. He overcomes himself finally, and his soul also gets rescued eventually. From the tragedy of his life, we realize that everyone should be honest and brave enough to face anything, only by confessing his faults bravely and willing to be punished, he can avoid destroying himself.

Chillingworth, who changes from a sympathetic victim to a crazy and frightening avenger, becomes a devil ultimately, destroys others and him. He delights in revenge and has no compassion. His tragic life tells readers that the vicious revenge mentality cannot bring good fortune. We should learn to forgive in the face of others' faults. Actually, the tolerance of others' faults is also the tolerance to oneself at the same time, so we should learn to be tolerant.

\section{CONCLUSION}

In one's life, making some mistakes is inevitable. Do not be afraid of making mistakes, the key is your attitude to them. To face the mistakes is to avoid making them to disasters, is an effective way to repeat similar mistakes, a kind of progress and the sublimation of thinking and understanding. Because of Hester's bravely facing her own mistakes, she finally finishes the rise of her personality and achieves the change from shame to glory. Dimmesdale's hide is at the expense of the loss of his life in the end.

So we should not escape when make some mistake, look into our faults directly, take out our courage to correct, assume the responsibility and make amends. Through reform and taking on, we can achieve the sublimation of life and realize the transcendence of life finally. At the same time, we should learn to be more tolerant in the face of others' faults. Tolerance need us have a forbearing heart to understand other people's faults, and not haggle over every ounce for such a trifle. Tolerance is a virtue, a kind of manner. Tolerant to others, you are a noble man; Tolerant to yourself, you are a wise man. Learn to be tolerant; our life will be natural and unrestrained.

\section{REFERENCES}

[1] [1] J. Tan, An analysis of causes of Hester's tragedy in The Scarlet Letter, Journal of Language and Literature Studies, 2012 (9), pp. 41-42

[2] [2] N. Hawthorne,. 1996. The Scarlet Letter [M]. Beijing: The Commercial press, pp. 45-52

[3] [3]Y. Song, On the character of the characters in the Scarlet letter, Academic Forum, 2011（12）, pp. 92-95 